Bergersen, F. J. \& Briggs, M. J. (1958). J. gen. Microbiol. 19, 482-490.

\title{
Studies on the Bacterial Component of Soybean Root Nodules: Cytology and Organization in the Host Tissue
}

\author{
By F. J. BERGERSEN AND MARGARET J. BRIGGS \\ Division of Plant Industry, C.S.I.R.O., Canberra, A.C.T. and John Curtin School of \\ Medical Research, Australian National University, Canberra, A.C.T., Australia
}

SUMMARY: Light- and electron-microscope studies of bacteroids in soybean nodule sections and suspensions of isolated bacteroids have shown well-defined nuclear elements, containing tangled filaments and dense granules. The cytoplasm was poorly stained as seen in the light microscope but had considerable dye-reducing activity localized at the poles, giving the appearance of granules. However, electron micrographs revealed no electron dense granules in the cytoplasm near the poles. Cell walls were not found on bacteroids in suspensions isolated from nodules, but were present on bacteria grown in vitro, and on bacteroids in the host tissue. Electron micrographs of thin sections of mature nitrogen-fixing nodules revealed a system of double membranes enclosing groups of four or six bacteroids. These membranes appeared to originate from the host cells and their development was followed in nodules aged from 1-5 weeks; they could be centrifugally separated from the bacteroid fraction of crushed nodules. The origin of the membrane system and its possible role in nodule functions is discussed.

In continuing the study of the bacterial component of soybean root nodules, the term 'bacteroid' is again used to denote the non-proliferating bacteria found in large numbers in the cytoplasm of the cells of the central tissue of mature nitrogen-fixing nodules; earlier proliferating stages in developing nodules are referred to simply as bacteria (Bergersen, 1958). This paper reports light- and electron-microscope studies of the bacteroids and their organization in nodule cytoplasm. Nodules of various ages are also examined in order that the development of the bacteroids and their attendant structures might be followed. The main features of the findings are illustrated by selected electron micrographs and diagrams.

\section{METHODS}

Plant and bacterial material. Plants were grown in the same conditions as before and nodules, cultures, and bacteroid suspensions were prepared as described by Bergersen (1958).

Light microscopy. Bright field microscopy was done with Wild 'Fluotar' objectives and for phase-contrast microscopy of unstained sections and bacteroid suspensions, the Wild 'Varicolor' system was employed (Bergersen, 1957). Microtome sections of nodules were examined unstained or stained by the rose bengal + light green method (Brenchley \& Thornton, 1925). Bacterial preparations were examined mounted in $\mathbf{M} / \mathbf{1 5}$ phosphate buffer $(\mathrm{pH} 7 \cdot 0)$, unstained, by phase contrast; they were stained with Janus green B (0.005\%, $\mathrm{w} / \mathrm{v}$ ) and tetrazolium blue (BT, $\mathbf{0} \cdot 1 \mathrm{mg} . / \mathrm{ml}$.) for the demonstration of reducing 
sites. Nuclear material in the bacteria and bacteroids was stained by the HCl-Giemsa method (Robinow, 1942) after fixation in $1 \%(\mathrm{w} / \mathrm{v})$ osmic acid in phosphate buffer $\left(\mathrm{pH} \mathrm{7.0)}\right.$ followed by $3 \mathrm{~min}$. hydrolysis in $\mathrm{N}-\mathrm{HCl}$ at $60^{\circ}$. Basic fuchsin $1 \%(\mathrm{w} / \mathrm{v})$ in $5 \%(\mathrm{w} / \mathrm{v})$ phenol in water was also found useful as a nuclear stain for bacteroids, no hydrolysis being required. Lipid material was stained by Sudan black B $(\mathbf{0 \cdot 2 5} \%, \mathrm{w} / \mathrm{v})$ in ethylene glycol. Cell walls were stained with $1 \%(\mathrm{w} / \mathrm{v})$ crystal violet after $20 \mathrm{~min}$. treatment with $10 \%(\mathrm{w} / \mathrm{v})$ tannic acid.

Electron microscopy. Material for electron microscopy was prepared as follows.

(a) Nodules. These were cut into strips $0.5-1 \cdot 0 \mathrm{~mm}$. wide and $0.5-1 \cdot 0 \mathrm{~mm}$. thick, and quickly immersed in cold $1 \%(\mathrm{w} / \mathrm{v})$ osmic acid in $\mathrm{m} / 15$ phosphate buffer $(\mathrm{pH} \mathrm{7 \cdot 0)}$. After $4 \mathrm{hr}$. fixation, the tissue pieces were washed in distilled water and dehydrated through a graded ethanol + water series into absolute ethanol, followed by two changes of $n$-butyl methacrylate monomer, and two changes of partially polymerized methacrylate, then finally polymerized at $70^{\circ}$ for $2 \mathrm{hr}$. Thin sections were cut with a Farrant \& Powell (1956) thermal expansion microtome, mounted on collodion-coated copper grids, and examined in an R.C.A. model EMU-3B electron microscope, micrographs being made at magnifications between 5000 and $\mathbf{1 2 , 0 0 0}$ diameters followed by further photographic magnification.

(b) Bacteria. Suspensions of bacteroids from crushed nodules, prepared as previously described (Bergersen, 1958) and bacteria from culture were centrifuged and re-suspended in $\mathrm{M} / 15$ phosphate buffer ( $\mathrm{pH} 7 \cdot 0$ ) containing $1 \%$ $(w / v)$ osmic acid. The cells were then centrifuged down, washed in water to remove excess osmic acid and then dehydrated by centrifugation and resuspension in 30, 60,90\% $(\mathrm{v} / \mathrm{v})$ ethanol in water and finally in absolute ethanol: the pellet was then embedded by the procedure described above.

\section{RESULTS}

\section{Structure and cytology of bacteroids from nitrogen-fixing nodules}

Light microscopy. The bacterial component (bacteroids) of nitrogen-fixing nodules consisted of rods $(3-5 \times 0.5 \mu)$ with slightly swollen ends which gave them a club-shaped appearance. Bacteria of the same strain grown in vitro had similar dimensions, but were parallel sided. The features of the bacteroids seen by the various staining procedures are summarized in Fig. 1. The nuclear material was in two forms: (i) discrete, more or less spherical bodies surrounded by the unstained perinuclear area (Bergersen, 1955); (ii) elongated, less intensely staining bodies, occupying half to two-thirds of the length of the cells in an axial position. The perinuclear area was diminished or absent with the latter type of nucleus. In all cases the cytoplasm stained poorly with basic dyes and with Janus green B and BT except for localized areas near the poles of the cells, where Janus green $B$ was rapidly reduced through the pink to the leuko form and blue formazan was rapidly deposited from BT. In the case of BT this effect became more pronounced when sodium succinate or sodium 
glutamate was added to the buffer at a concentration of $0.02 \mathrm{M}$. These active polar areas had the appearance of granules and were stained by Sudan black B and osmic acid. They were similar in size to granules with the same activities seen in clover nodule bacteroids (Bergersen, 1955).

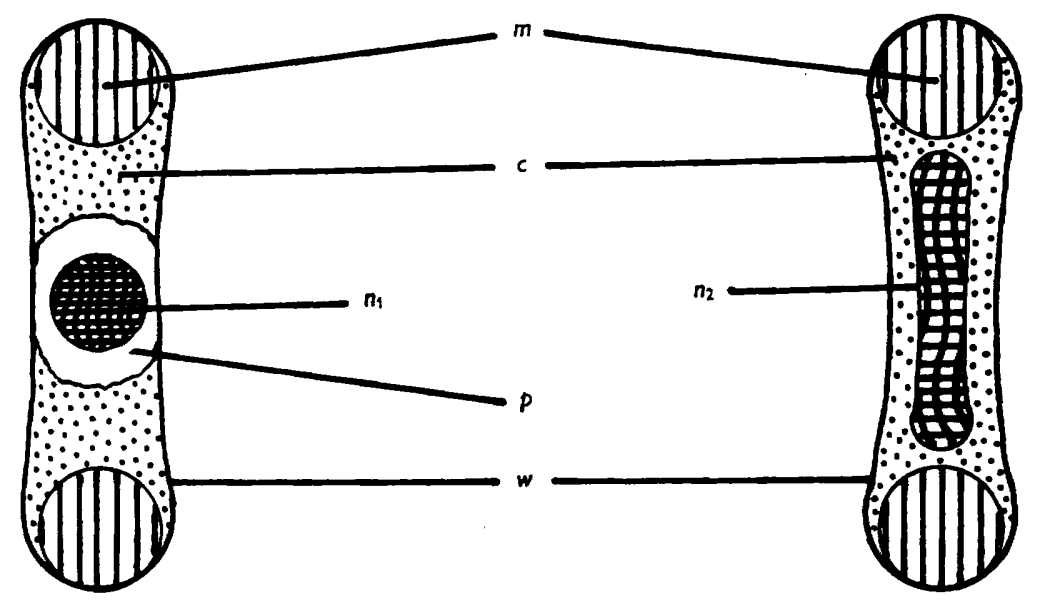

Fig. 1. The cytological features of the two types of bacteroids separated from mature, nitrogen-fixing soybean root-nodules as seen by light microscope methods. $c$, cytoplasm with low affinity for stains; $w$, cell margins unstained by cell-wall stains, but having osmiophilic properties; $m$, polar regions of reducing activity with respect to janus green $\mathrm{B}$, and tetrazolium dyes; $n_{1}$, intensely staining chromatinic material surrounded by an unstained perinuclear area, $p ; n_{2}$, elongated less intensely stained nuclear material.

Electron microscopy. Bacteroids seen in thin sections of nodule tissue or thin sections of embedded suspensions isolated from crushed nodules, possessed clearly defined nuclei whose shape and position agreed closely with the chromatinic bodies stained in whole cells by the HCl-Giemsa method and seen in the light microscope. In detail the nuclei consisted of intertwined filamentous material and several dense granules in an electron transparent matrix, but without any limiting membrane (Pl. 4, fig. 5). In the elongated nuclei the filaments were fine and loosely interwoven, while in the compact nuclei, which are not illustrated, they were thicker and very tangled. Along the latter type of nucleus appeared a diffuse osmiophilic or electron dense region corresponding to the position of the non-staining perinuclear areas. The cytoplasm of the bacteroids was vacuolated and there were no structurally recognizable polar granules: instead there appeared to be spaces in the cytoplasm at the positions occupied by the dye-reducing areas described in the previous section (Pl. 4, fig. 5; Fig. 1). This may have been due to the presence of electron-transparent material or loss of material during embedding as suggested by Chapman (private communication) in relation to the 'peripheral bodies' of Bacillus cereus described by Chapman \& Hillier (1953). Bacteroids in suspensions isolated from crushed nodules had no cell wall, the cytoplasmic boundary simply had a sharply defined margin. However, in nodule sections a mem- 
branous wall surrounded each bacteroid: sectioned bacteria from culture also possessed cell walls (Pl. 4, figs. 6, 7).

In the sections of the younger nodules the bacteria had denser unvacuolated cytoplasm except in the polar positions where small vacuoles appeared, and the nucleus was usually elongated, the filaments again being plainly visible (Pl. 2, fig. 3). In nodules aged from 1 to 2 weeks the bacteria were still actively dividing (Bergersen, 1958), and at 3 weeks bacteroid formation was about complete. No marked cytological changes were seen at this point in the present study: this is in contrast to the formation of bacteroids in subterranean clover nodules (Bergersen, 1955) where changes in shape and nuclear arrangement were readily seen.

\section{The organization of bacteroids in mature, nitrogen-fixing nodules}

In microtome sections of nodules examined in the light microscope, the bacteriods were apparently randomly packed into the cytoplasm in the host cells. Remnants of host nuclei were still visible and there were several small vacuoles in the host cytoplasm of bacteroid-containing cells. Electron micrographs of thin sections of similar nodules revealed the bacteroids lying within a membrane system in the host cytoplasm. Individual bacteroids lying within their cell walls in groups of two, four or six were surrounded by a membrane envelope (Pl. 1), whose double-layered structure is seen in Pl. 4, fig. 8. In most preparations there was a certain amount of shrinkage of the bacteroids resulting in empty spaces between them and their cell walls; it is probable that in life these were closely applied to the surface of the bacteroids.

The space between the bacteroid walls and the membrane envelope was occupied by diffuse or slightly granulated material. The host cytoplasm between the enclosed groups of bacteroids was composed of rather diffuse granular material with numbers of structures interpreted as tubules cut in various planes (Pl. 1). The significance of these will be discussed below.

\section{The organization of the bacteria in developing nodules}

In order to follow the development of the membrane system, tissue from nodules aged from 1 to 5 weeks was examined by light and electron microscopy. Bacterial numbers were low in infected cells of one week old nodules and slender infection threads could be seen with the light microscope in the majority of host cells of the central tissue. These threads traversed dividing cells whose nuclei were in various stages of mitosis, and free bacteria were also seen in dividing host cells. Infection threads were difficult to find in the cells of 2 weeks or older nodules, although many dividing cells containing bacteria were seen. It seemed, therefore, that initially the bacteria were distributed through the dividing cells of the young developing nodule by ramifications of infection threads from which the bacteria were released into the cytoplasm of the cells, the bacteria being continuously re-distributed by division of the host cells containing them. Host cell division became less frequent and finally ceased after about 2 weeks from the first appearance of the nodule, while the 
bacteria then multiplied until the swelling host cells were fully packed with them.

Electron micrographs of thin sections of 1-week-old nodules were obtained which contained portions of infection threads (PI. 2, fig. 2). These were enclosed in well-defined double membranes, inside which was a layer of material presumed to be the cellulose walls of the thread (McCoy, 1932; Schaede, 1940, 1941). Within these walls the cell wall of the bacteria could be seen, separated by the embedding procedures from the cell surface. A number of sections of 1-week-old nodules showed single, isolated bacteria, few in number and enclosed in the double membranes. In other sections the bacteria, similarly enveloped, appeared in a group near the host-cell nucleus (Pl. 2, fig. 3; Pl. 3, fig. 4).

In electron micrographs of sections of 2-week-old nodules the bacteria were present in greatly increased numbers, each enclosed by a membrane. In nodules aged 3 weeks individual bacteria were enclosed in groups of two or sometimes four bacteria within the envelope; 4- and 5-week-old nodules contained the structures of the mature nodules described in the previous section. In all micrographs of 2- to 5-week-old nodules the sectioned cytoplasmic tubules mentioned previously could be readily found. They were particularly plentiful in nodules aged 3 weeks, scattered in the cytoplasm between the membranes.

During the development of the bacteroids and their attendant membranes the host cytoplasm also changed considerably. The cytoplasm of the young host cells was typical of plant meristem (Heitz, 1957; Lance, 1957) and contained normal mitochondria, scattered Golgi regions and many ribonucleoprotein granules (RNP) some of which were associated with the membranes of the endoplasmic reticulum. With increasing age, the cytoplasm became less dense and RNP and Golgi regions disappeared, mitochondria became scarce and were confined to the cell periphery, and endoplasmic reticulum was much reduced. The appearance of the nucleus was normal up to three weeks. These changes were attendant on large increases in host cell volume, as seen in light microscopy of microtome sections of nodules.

\section{Isolation of the membranes}

The prominence and relative abundance of the membrane system described in previous sections, and the possibility that it may be concerned in processes vital to the functioning of the nodules, prompted an attempt to isolate samples of it from crushed nodules. Light microscope examination of supernatant fluids after centrifugation of bacteroids, showed numbers of sack-like bodies visible with the 'Varicolor' phase equipment when using green light of about $520 \mathrm{~m} \mu$ wavelength. It was then found that by prolonged centrifugation at $6000 \mathrm{~g}$ of the filtered crushed nodules, these sack-like bodies were sedimented as a grey brown layer immediately overlying the bacteroids in the centrifuge tube. Such a preparation was made, the upper layer resuspended in $\mathrm{M} / 15$ phosphate buffer ( $\mathrm{pH} \mathrm{7.0)}$ ) and re-centrifuged. After a further wash in buffer, the preparation was fixed in cold $1 \%(\mathrm{w} / \mathrm{v})$ osmic acid in phosphate buffer, dehydrated, 
embedded in methacrylate and sectioned as described. The electron micrograph of Pl. 4, fig. 8, shows sections of the membranes whose thickness of $125 \AA$ corresponds to the thickness of membranes in sections of intact nodules, and whose two-layered structure is clearly demonstrated.

In view of the fact that bacteroids in suspensions from crushed nodules were largely devoid of cell walls, the preparations described in this section probably contained bacteroid walls as well as membrane envelope materials. The thicker fragments are thought to be wall material (Pl. 4, fig. 8).

\section{The cell walls of bacteria isolated from nodules of various ages}

The observation that mature bacteroids were devoid of cell walls when isolated from nodules as suspensions may have a bearing on the failure of growth of bacteroids. Suspensions of bacteria from nodules aged from 1 to 6 weeks were prepared and stained by the tannic acid + crystal violet method. Bacteria from nodules aged up to 2 weeks possessed intact cell walls but from 3 weeks no cell walls could be stained.

\section{DISCUSSION}

The cytology of the bacteroids and of the proliferating bacteria from in vitro cultures presented no unexpected features. The chief structural difference between bacteroids and growing bacteria lay in the density of the cytoplasm of the latter compared with the vacuolated poorly staining cytoplasm of the bacteroids. In both types of cells the nuclear material consisted of intertwined filaments and dense granules, and no limiting membrane. The discrete spherical nuclei, however, seemed to be characteristic of the bacteroids and may represent nuclei incapable of further division, thus, perhaps, contributing to the non-proliferating nature of the bacteroids. The filaments of the nuclei are similar to filaments described in nuclei of Salmonella (Maaløe \& BirchAndersen, 1956), Staphylococcus (Bradfield, 1956) and Escherichia coli (Tomlin \& May, 1955), to quote but a few examples.

The fact that bacteroids in suspension are largely devoid of their cell walls may also contribute to the failure of growth of bacteroids when placed in normal culture media (Almon, 1933). It is also interesting to note that the loss of bacterial dry weight reported previously when nodules are between 1 and 2 weeks old (Bergersen, 1958) may have been in part at least, due to loss of cell-wall material during preparation of the suspension from crushed nodules.

The method used for fixing and embedding nodule material for electron microscopy was arrived at after trials of a number of fixation times, osmic acid concentrations, temperatures, buffers and salt concentrations. The use of $\mathrm{m} / 15$ phosphate buffer ( $\mathrm{pH} \mathrm{7 \cdot 0)}$ ) as both buffer and salt medium with fixation in $1 \%$ osmic acid in the cold, gave best preservation of host cytoplasm and minimum shrinkage of bacteroids. The variation in osmotic pressure of the fixative had little effect on the extent of bacterial shrinkage, which probably occurred during dehydration.

A discussion of the organization of the bacteroids within the membrane system which has been described would be incomplete if no hypothesis of the 
origin of the membranes were advanced. Figure 2 illustrates the author's proposals. It is suggested that the final organization results from outgrowths of the original infection thread, the outer membranes of which are pushed out before the bacteria as they grow out from the thread. This happens in host cells still undergoing division and connexion with the infection thread is soon

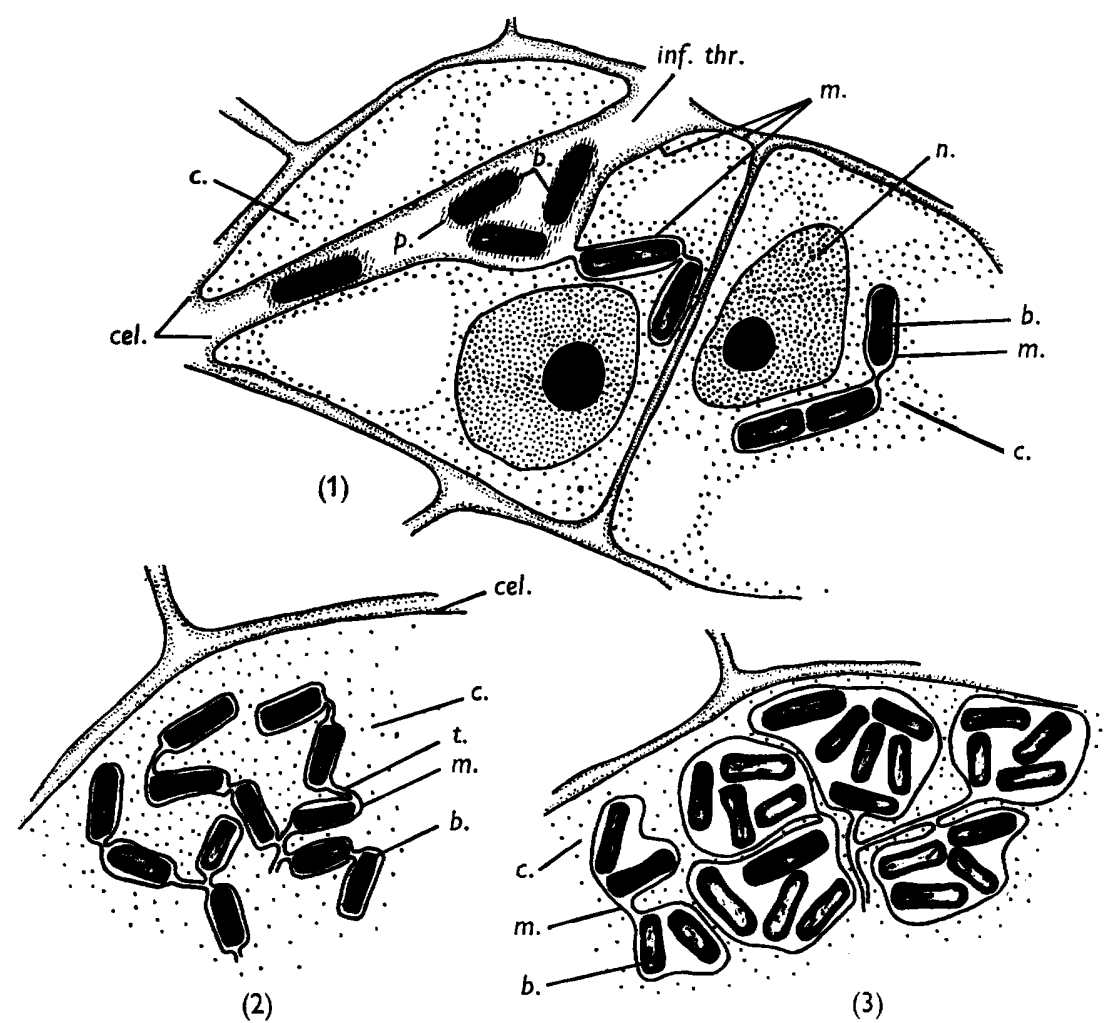

Fig. 2. Diagrammatic representation of the development of the membrane system enclosing the bacteroids in soybean root-nodules. (1) Bacteria escape from the cellulose-thickened infection thread, but are still enclosed by the thread membrane which is continuous with the host cell membrane. The host cell then divides and a small group of bacteria surrounded by the membrane is separated from the original infection thread by the developing cell wall. (2) Bacteria multiply within the enclosing membranes, the development of which keeps pace with bacterial multiplication, with the result that the bacteria become individually surrounded by inter-connected membrane envelopes. (3) The final stages in which the divisions of the bacteria result in groups within the enveloping membranes, firstly in pairs and ultimately in groups of four or six. c., host cytoplasm; cell., cellulose of host cell walls and lining infection threads, inf.thr.; m., membrane envelope around bacteria, and initially continuous with infection thread membrane and host cell-membrane; $n$., host nucleus ; $b$., bacteria; $t$., interconnecting membrane tubule.

broken. The result is a distribution of bacteria in low numbers throughout the central tissue of the nodules, each bacterium surrounded by extensions of the thread membranes, seen as a membrane enclosing each cell. The bacterial growth which takes place, subsequent to cessation of host cell division, occurs within the membranes, growth of which keeps pace with bacterial multipli- 
cation to give, at 2 weeks from the first visible appearance of the nodules, a large number of bacteria, each surrounded by inter-connected membranes. The sectioned tubules mentioned earlier represent the interconnecting portions of the system. The last few bacterial divisions occur in conditions where space is limited and the bacteria can no longer extend the tubules, with the result that the outer membrane is extended to form a sack, containing at first a pair of bacteria and later four or six bacteroids.

Nutman (1956) suggested that infection thread development is really an inward growth of the cell wall at the point of penetration. If this be so, the outer membrane of infection threads and the membrane envelope enclosing the bacteria may be regarded as being homologous with the host cell membrane. The dimensions of both (125 $\AA$ in thickness) are similar and this tends to support the hypothesis. One electron micrograph, which is not presented, has clearly shown that the thread membrane was continuous with the host cell membrane.

It is worthy of note that nitrogen fixation, in the system being studied in this work, begins when the nodules are between 2 and 3 weeks old and attains its maximum rate a week later (Bergerson, 1958). These times correspond to the final stages of development of the membrane system. It thus seems possible that this may be concerned in the organization of enzymes involved in the fixation of molecular nitrogen or in the assimilation of the reduced product into the metabolism of the host plant.

The authors wish to thank Miss L. Tyrell for valuable technical assistance. This is the second paper of a series reporting studies of the bacteria of soybean root nodules.

\section{REFERENCES}

Almon, L. (1933). Concerning the reproduction of bacteroids. Zbl. Bakt. 87, 289.

Bergersen, F. J. (1955). The cytology of bacteroids from root nodules of subterranean clover (Trifolium subterraneum L.). J. gen. Microbiol. 13, 411.

BERGERSEN, F. J. (1957). The occurrence of a previously unobserved polysaccharide in immature infected cells of root nodules of Trifolium ambiguum M. Bieb. and other members of the Trifoliae. Aust. J. biol. Sci. 10, 17.

Bergersen, F. J. (1958). The bacterial component of soybean root nodules; changes in respiratory activity, cell dry weight and nucleic acid content with increasing nodule age. J. gen. Microbiol. 19, 312.

Bradfield, J. R. G. (1956). Organization of bacterial cytoplasm. In Bacterial Anatomy, p. 316. Symp. Soc. gen. Microbiol. 6, 316.

Brenchley, W. E. \& Thornton, H. G. (1925). The relation between the development, structure and functioning of the nodules of Vicia faba as influenced by the presence or absence of boron in the nutrient medium. Proc. Roy. Soc. B, 98, 373.

Chapman, G. B. \& Hillier, J. (1953). Electron microscopy of ultra-thin sections of bacteria. I. Cellular division in Bacillus cereus. J. Bact. 66, 362.

Farrant, J. L., \& Powell, S. E. (1956). Proceedings of the First Regional Conference on Electron Microscopy in Asia and Oceania, p. 147. Electro-Technical Laboratory, Tokyo.

HeITz, E. (1957). Über Plasmastrukturen bei Antirrhinum majus und Zea mais. Z. Naturf. $12 b, 579$.

Lance, A. (1957). Sur l'infrastructure des cellules apicales de Chrysanthemum segetum L. C.R. Acad. Sci., Paris, 245, 352. 
MAaløe, O. \& Birch-Andersen, A. (1956). On the organization of the 'Nuclear Material' in Salmonella typhimurium. In Bacterial Anatomy, Symp. Soc. gen. Microbiol. 6, 261.

McCoy, E. (1932). Infection by Bact. radicicola in relation to the microchemistry of the hosts' cell walls. Proc. Roy. Soc. B, 110, 514.

Nutman, P. S. (1956). The influence of the legume in root-nodule symbiosis. Biol. Rev. 31, 109.

Robinow, C. F. (1942). A study of the nuclear apparatus of bacteria. Proc. Roy. Soc. B, 130, 299.

SchaEde, R. (1940). Die Knöllchen der adventiven Wasserwurzeln von Neptunia oleraceae und ihre Bakteriensymbiose. Planta, 31, 1.

Schakde, R. (1941). Untersuchungen an den Wurzellknöllehen von Vicia faba und Pisum sativum. Beitr. Biol. Pfl. 27, 165.

TombIn, S. G. \& MaY, J. W. (1955). Electron microscopy of sectioned bacteria. A study of Esch. coli. Aust. J. exp. Biol. Sci. 33, 249.

\section{EXPLANATION OF PLATES}

Electron micrographs of thin sections of soybean nodule tissues, preparations of bacteroids and cultured bacteria, fixed in $1 \%(\mathrm{w} / \mathrm{v}) \mathrm{Os}_{4}$ in $\mathrm{M} / 15$ phosphate buffer.

Plate 1

Fig. 1. Mature bacteroid-containing cell of a 3-week-old nodule showing bacteroids $(b$. $)$ in transverse section with their cell walls $(c . w$.) separated during preparation, from the cell surfaces. The bacteroids in groups of two, four and six are surrounded by a membrane envelope $(m$.$) and the host cytoplasm (c$.$) is very diffuse and featureless. A number$ of sectioned tubules $\left(t_{0}\right)$ are associated with the membranes. Magnification, $\times 77,000$.

Plate 2

Fig. 2. A section of a portion of an infection thread in a 1-week-old nodule; it runs through a strand of cytoplasm with vacuole $(v$.$) on either side. The membrane (m$.$) around the$ thread is clearly visible and the grey lining of the thread is interpreted as the cellulose layer $(\mathrm{cel}$. .): this is absent from the portion on the right which is interpreted as the first stage in the movement of the bacteria $(b$.$) from the infection thread into the host$ cytoplasm (see Fig. 2). Magnification, $\times 91,000$.

Fig. 3. A section of a portion of a cell of a 1-week-old nodule, in which individual bacteria enclosed in membranes $(m$.$) are distributed throughout the cytoplasm of the host cell.$ The bacteria have dense cytoplasm and their nuclei contain filaments $(n . f$.$) . Magnifi-$ cation, $\times 136,000$.

\section{Plate 3}

Fig. 4. A slightly younger cell than in Fig. 3: a group of individually enclosed bacteria are seen near the host nucleus $(h . n$.). The host cytoplasm is typical of young plant cells and contains numerous RNP granules (r.n.p.): endoplasmic reticulum (e.r.) and Golgi regions (g.r.) are present. Magnification, $\times 141,000$.

\section{Plate 4}

Fig. 5. A longitudinal section of a bacteroid from a suspension isolated from 4-week-old nodules. Polar reducing sites (r.s.) appear as spaces in the cytoplasm and the axial nuclear material consists of fine filaments $(n . f$.$) in an electron transparent matrix with$ two dense granules $(n . g$.$) . There is no cell wall. Magnification, \times 116,000$.

Figs. 6, 7. Rhizobium japonicum, strain C.C. 711 grown on yeast + mannitol agar. Cell walls (c.w.) are present although separated from the cell surface, by shrinkage of the protoplast. The nuclei contain filaments (n.f.) and granules (n.g.). Magnification, $\times 77,000$

Fig. 8. Membranes isolated from crushed nodules. The double-layered structure is elearly shown $(m$.$) and thicker fragments represent bacterial cell-wall material (c.w.).$ Magnification, $\times 119,000$. 
Journal of General Microbiology, Vol. 19, No. 3

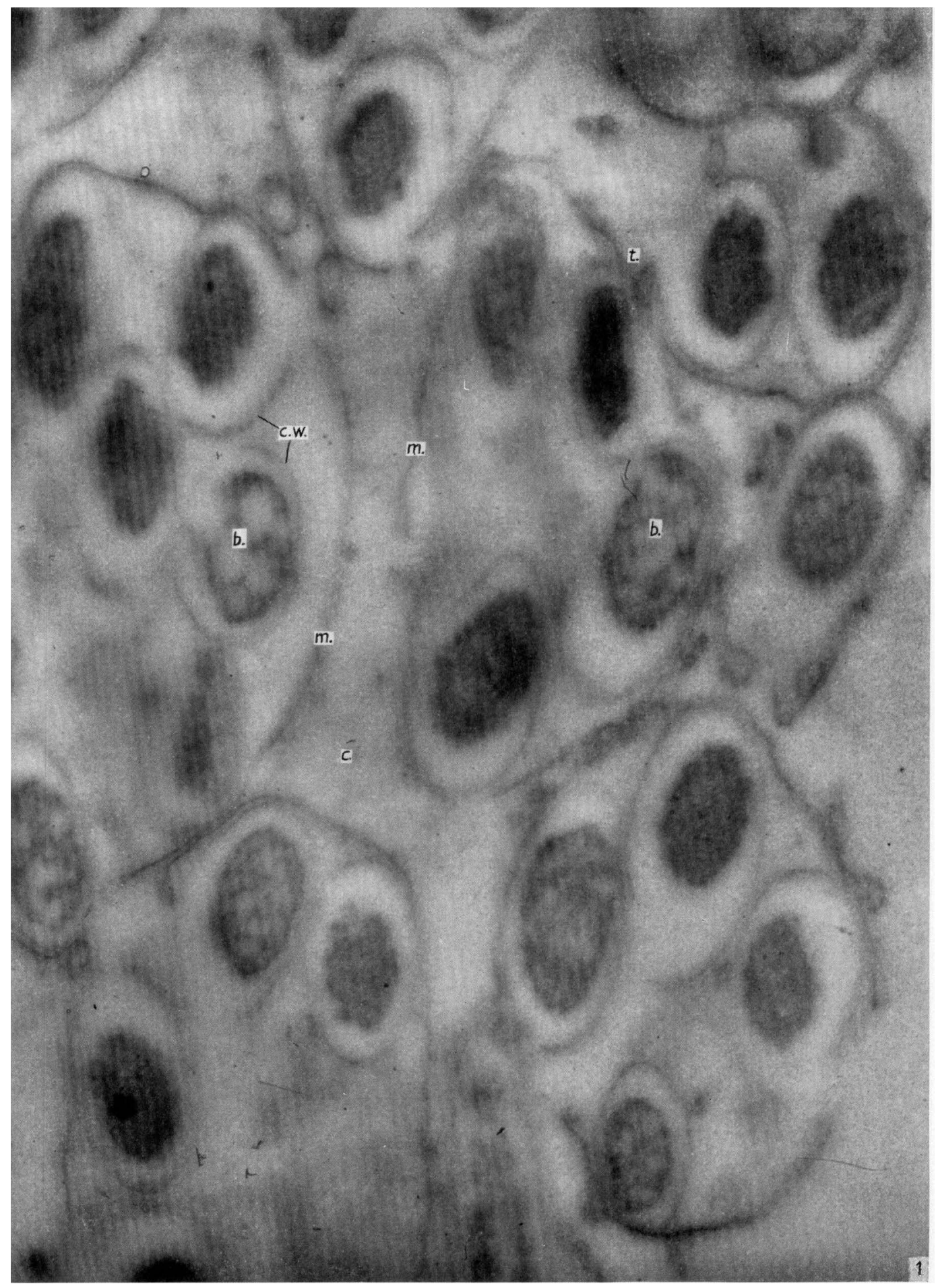

F. J. Bergersen \& M. J. Briggs-The bacterial component of soybean root nodules. Plate 1 
Journal of General Microbiology, Vol. 19, No. 3
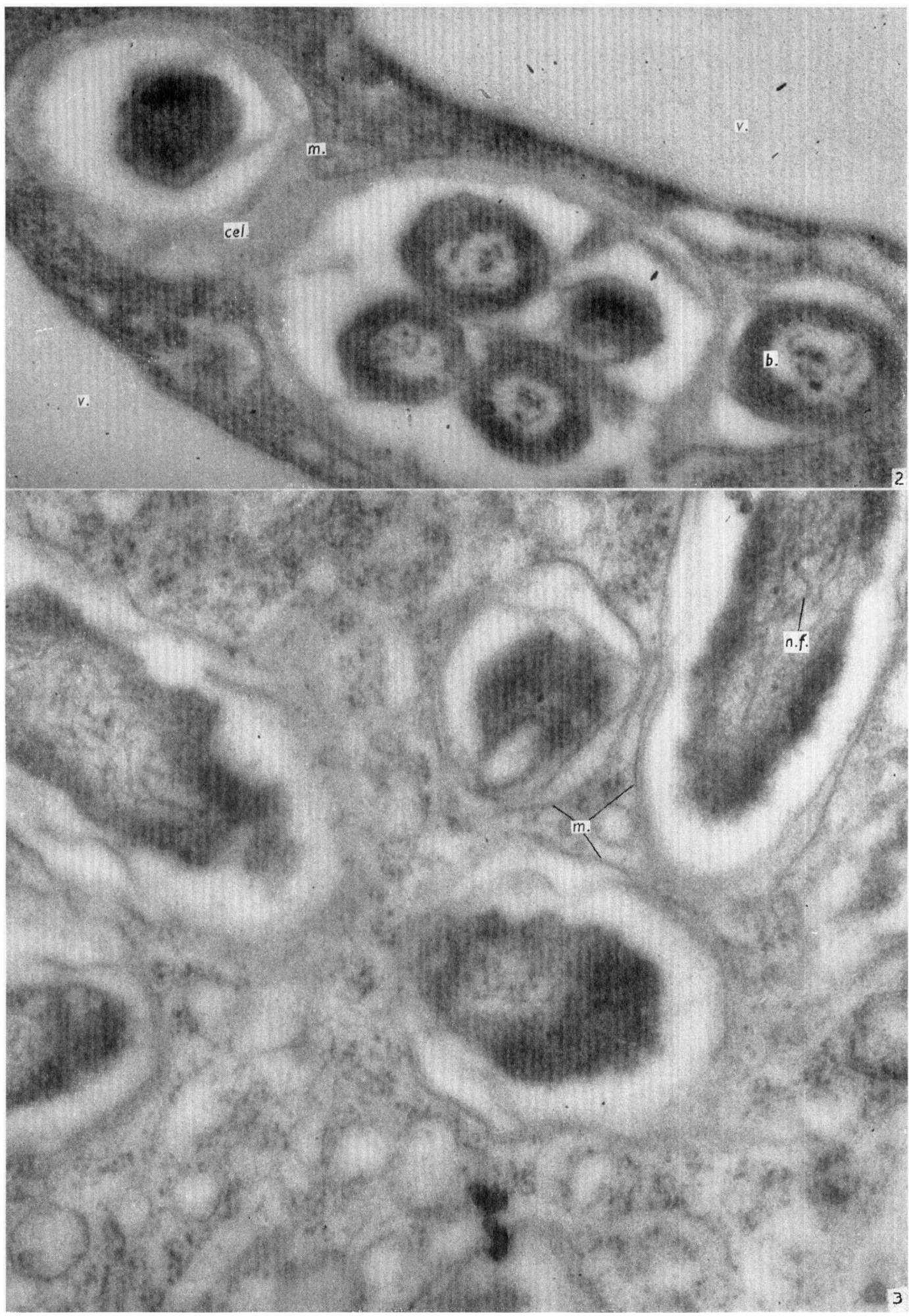

F. J. Bergersen \& M. J. Briggs-The bacterial component of soybean root NODUles. Plate 2 
Journal of General Microbiology, Vol. 19, No. 3

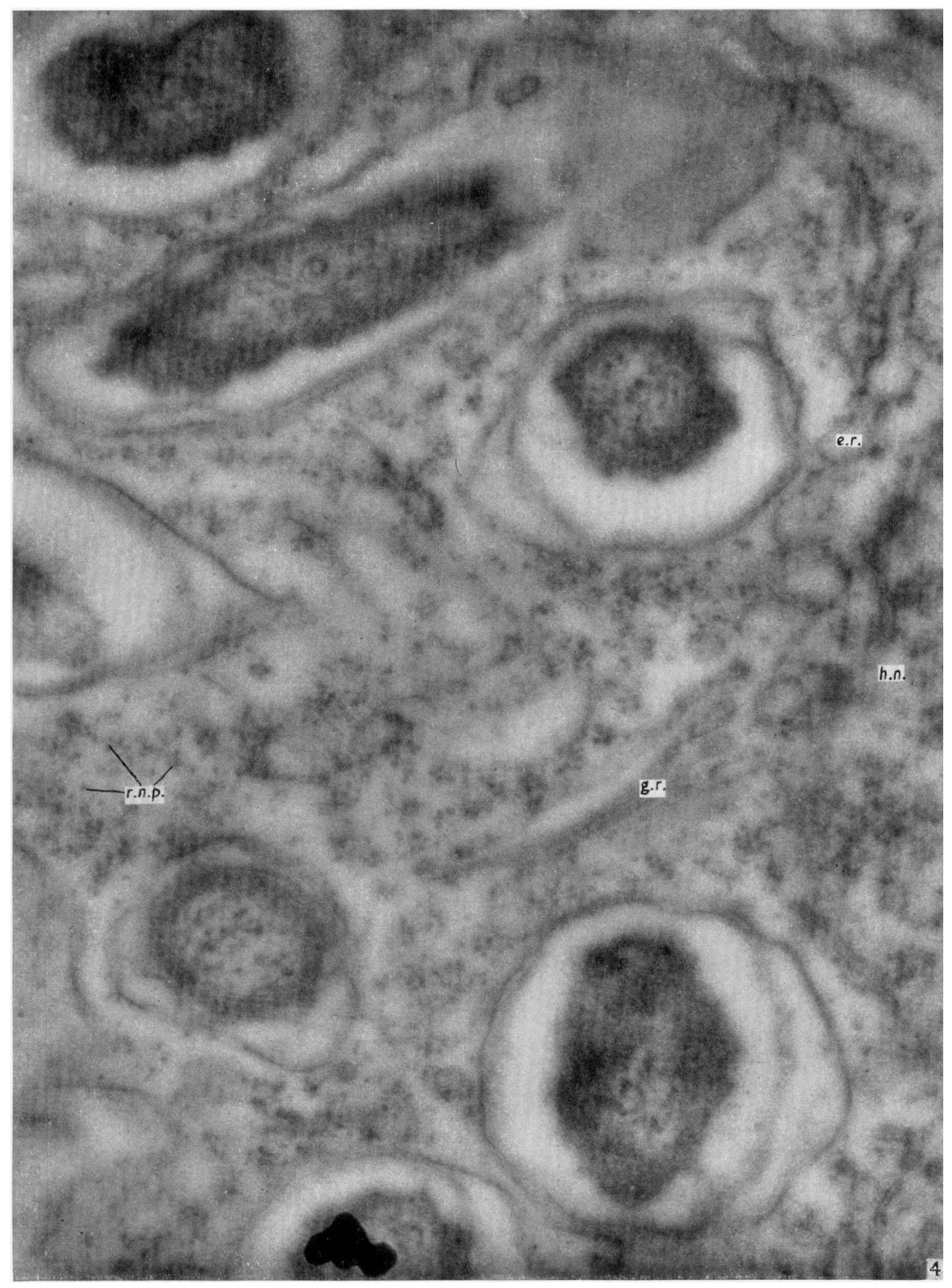

F. J. Bergersen \& M. J. Briggs-The bacteriat component of soybean root nodules. Plate 3 
Journal of General Microbiology, Vol. 19, No. 3

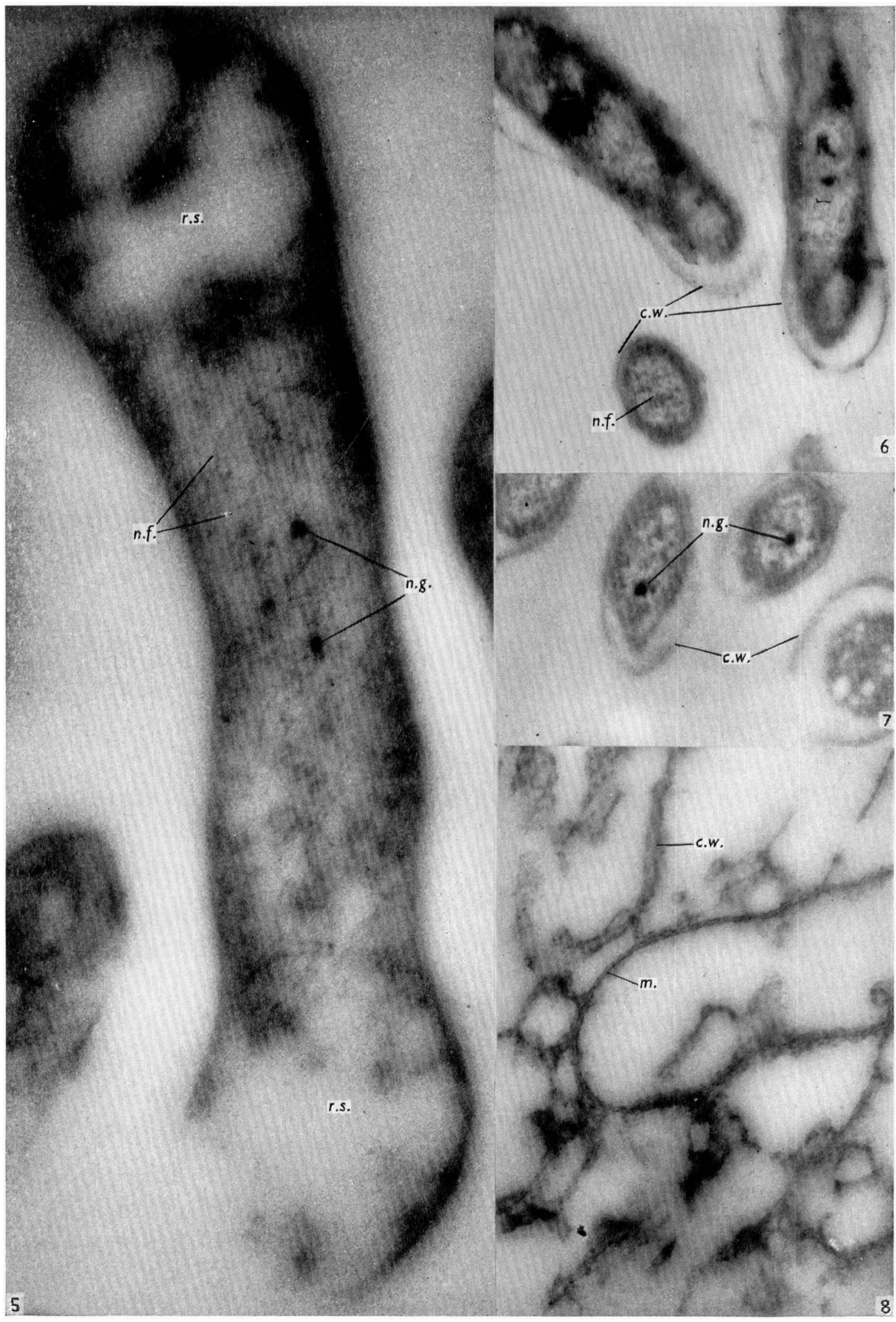

F. J. Bergersen \& M. J. Briggs-The bacterial component of Soybean root nodules. Plate 4 